\title{
Aktivitas Anti-inflamasi Ekstrak Etanol Daun Beluntas (Pluchea indica L.) pada Model Inflamasi Terinduksi CFA (Complete Freund's Adjuvant)
}

\section{(Anti-inflammatory Activity of Ethanol Extract of Beluntas Leaves(Pluchea indica L.) on Complete Freund's Adjuvant-induced Inflammatory Model)}

\author{
Reza Setiawan Sudirman, Usmar, Abdul Rahim dan Muhammad Akbar Bahar*
}

Fakultas Farmasi, Universitas Hasanuddin, Makassar, Indonesia

\author{
Article Info: \\ Received: 04 September 2017 \\ in revised form: 22 Seeptember \\ 2017 \\ Accepted: 29 September 2017 \\ Available Online: 01 Oktober 2017

\section{Keywords:} \\ Anti-inflammatory, \\ Beluntas Leaves, \\ Pluchea indica, \\ CFA
}

Corresponding Author:

Muhammad Akbar Bahar

Fakultas Farmasi,

Universitas Hasanuddin

Makassar, 90245, Indonesia

Mobile : +31636432643

Email: akbarbahar@unhas.ac.id

\begin{abstract}
A research about anti-inflammatory effect of Beluntasleaves extract on CFA (Complete Freund's Adjuvant) induced inflammatory model has been conducted. The objective of this research was to determine the effect of Beluntasleaves extract in alleviating CFA-induced paw edema in mice (Mus musculus). The number of mice used was 15 and was divided into 5 groups. Group I was treated with NaCMC. Group II, III, and IV were given suspension of Beluntasleaves extract $100 \mathrm{mg} / \mathrm{Kg}, 300 \mathrm{mg} / \mathrm{Kg}$, and $500 \mathrm{mg} / \mathrm{KgBW}$, respectively. Group $\mathrm{V}$ was a positive control treatedwith suspension of diclofenac sodium $0.1 \mathrm{ml} / 10 \mathrm{~g}$ orally. The determination of anti-inflammatory potency was based on the average time needed to amelioratethe edema volume. The shortest time period of edema reduction was produced by diclofenacsodium(within 9.33 days), then followed by Beluntasleavesextract with the concentration of $300 \mathrm{mg} / \mathrm{Kg}$ (within 12 days), $500 \mathrm{mg} / \mathrm{Kg}$ (within 14.33 days), and $100 \mathrm{mg} / \mathrm{Kg}$ (within 17.67 days), consecutively. These results are significantly different compared to negative control group which did not reduce the edema volume during 18 days of observation.In conclusion, ethanol extract of Beluntasleaves has an effective anti-inflamatory effect.
\end{abstract}

Copyright $\odot 2017$ JFG-UNTAD

This open access article is distributed under a Creative Commons Attribution (CC-BY-NC-SA) 4.0 International

How to cite (APA 6th Style):

Sudirman RS., Usmar., Rahim A., Bahar MA. (2017). Aktivitas Anti-inflamasi Ekstrak Etanol Daun Beluntas (Pluchea indica L.) pada Model Inflamasi Terinduksi CFA (Complete Freund's Adjuvant). Jurnal Farmasi Galenika (Galenika Journal of Pharmacy), 3(2), 191-198. doi: 10.22487/j24428744.2017.v3.i2.8921 


\begin{abstract}
ABSTRAK
Telah dilakukan penelitian tentang uji potensi antiinflamasi ekstrak daun Beluntas (Pluchea indica L.) dengan model inflamasi terinduksi CFA (Complete Freund's Adjuvant). Penelitian ini bertujuan untuk mengetahui efek ekstrak daun Beluntas terhadap penurunan volume udema pada kaki mencit (Mus musculus) yang diinduksi dengan CFA secara intraplantar. Mencit yang digunakan sebanyak 15 ekor dan dibagi dalam 5 kelompok. Kelompok I diberi perlakuan NaCMC, kelompok II diberi suspensi ekstrak daun Beluntas 100 $\mathrm{mg} / \mathrm{Kg}$, kelompok III diberi suspensi ekstrak daun Beluntas $300 \mathrm{mg} / \mathrm{Kg}$, kelompok IV diberi suspensi ekstrak daun Beluntas $500 \mathrm{mg} / \mathrm{Kg}$, dan kelompok $\mathrm{V}$ diberi suspensi natrium diklofenak dengan volume pemberian secara oral $0,1 \mathrm{ml} / 10 \mathrm{~g}$. Pengamatan uji potensi antiinflamasi didasarkan pada rata-rata kecepatan hari penyembuhan udema pada kaki mencit dengan waktu pengamatan selama 18 hari. Rata-rata kecepatan hari penyembuhan udema yang tertinggi terlihat pada kelompok kontrol positif (natrium diklofenak) yaitu 9,33 hari kemudian diikuti ekstrak daun Beluntas dengan konsentrasi $300 \mathrm{mg} / \mathrm{Kg}$ yaitu 12 hari, setelah itu ekstrak daun Beluntas dengan konsentrasi 500mg/Kgyaitu 14,33 hari dan yang paling lama adalah ekstrak daun Beluntas dengan konsentrasi 100mg/Kg yaitu 17,67 hari. Sedangkan, kelompok kontrol negatif (NaCMC) belum mengalami penyembuhan selama 18 hari pengamatan. Analisis statistik (Two Way RM ANOVA) menunjukkan efek yang berbeda nyata antara kelompok perlakuan dan kelompok kontrol positif (natrium diklofenak) terhadap kelompok kontrol negatif (NaCMC). Kesimpulan penelitian adalah ekstrak etanol daun Beluntas memiliki efek antiinflamasi yang baik.
\end{abstract}

Kata Kunci: Antiinflamasi, daun Beluntas, Pluchea indica, CFA

\section{PENDAHULUAN}

Inflamasi adalah respon sistem

kekebalan tubuh terhadap infeksi dan kerusakan jaringan. Inflamasi juga terlibat dalam patogenesis berbagai seperti arthritis, kanker, stroke, penyakit-penyakit neurodegeneratif dan kardiovaskular. Tanda-tanda utama terjadinya inflamasi adalah rubor (kemerahan), kalor (panas), tumor (pembengkakan), dan dolor (nyeri) (Ricciotti E \& FitzGerald G.A, 2011). Ketika penyembuhan selesai, proses inflamasi biasanya reda. Namun, aktivasi yang tidak tepat dari sistem imun dapat menyebabkan inflamasi menjadi lebih persisten, terutama pada penyakit autoimun seperti rheumatoid arthritis (RA) (Harvey R.A et al., 2012).
Inflamasi mulai terjadi ketika ada stimulus, seperti infeksi, kerusakan sel yang disebabkan oleh faktor fisik, atau faktor kimia. Kerusakan ini dimulai dengan aktivasi faktor transkripsi yang mengontrol ekspresi banyak mediator inflamasi. Diantara mediator-mediator inflamasi yang berperan penting adalah eikosanoid, oksidan biologis, dan sitokin yang merupakan target utama pengobatan (Craig C.R. \&Stitzel R.E, 2003).

Beluntas(Pluchea indica $\quad$ L.) telah digunakan sebagai obat oleh masyarakat di Asia Tenggara seperti Thailand. Daunnya digunakan sebagai tonik saraf, antiinflamasi, wasir, anti nyeri, antipiuretik, mengeluarkan keringat, mengobati scabies, menghilangkan bau badan, 
meningkatkan nafsu makan, melancarkan pencernaan dan obat tuberkulosis (TBC) (Srisook K et al., 2012; Dalimartha S, 1999; Sibarani VR dkk., 2013). Secara empiris, penggunaannya dilakukan dengan cara merebus daun atau akar Beluntas sebanyak 10-15 g lalu diminum (Sibarani VR dkk., 2013).

Model hewan coba yang dapat digunakan untuk menguji efek antiinflamasi dapat dibuatdengan menginduksikan Complete Freund's adjuvant (CFA) pada hewan coba seperti mencit. CFA merupakan emulsi minyak dalam air, yang mengandung Mycobacterium tuberculosis kering yang telah di-matikan atau hanya berupa komponen dari dinding selnya (National Institutes of Health Intramural, 2015). Pemberian CFA akan menstimulasi fagositosis, sekresi sitokin oleh fagositosis mononuklear, sehingga berbagai jenis sitokin proinflamasi seperti TNF $\alpha$, IL-1, IL-6, IL-8, PGE-2, NO, MMP dan mediator lainnya akan dilepaskan (Fajrin F.A dkk., 2013). Berdasarkan uraian diatas, penelitian ini bertujuan untuk menguji efek antiinflamasi dari ekstrak daun Beluntas ( $P$. indica) menggunakan model inflamasi terinduksi CFA dengan mengamati laju penurunan volume edema pada kaki belakang mencit (Mus musculus).

\section{METODE PENELITIAN}

\section{Alat}

Alat-alat yang digunakan adalah connecta tree way, statif dan klem, spuit $3 \mathrm{ml}$, spuit insulin (Terumo $\left.{ }^{\circledR}\right)$, homogenizer (Ultra Turax ${ }^{\circledR} \mathrm{Ika}^{\circledR}$ Werve), mikropipet (Socorex®), neraca analitik
(Sartorius $\left.{ }^{\circledR}\right)$, rotary evaportor (Buchi $\left.{ }^{\circledR}\right)$, dan pengering herba.

\section{Bahan}

Bahan-bahan yang digunakan adalah air suling, Natrium CMC, eta-nol 70\%, etanol 96\%, ekstrak daun Beluntas (Pluchea indica L.), dan Compelete Freund's Adjuvant (CFA) (Sigma®).

\section{Pengambilan dan Pengolahan Sampel}

Sampel daun Beluntas yang digunakan diperoleh dari Kecamatan Somba Opu, Kabupaten Gowa, Sulawesi Selatan. Sampel dicuci bersih dengan air mengalir, kemudian dikeringkan dengan pengering herba lalu dipotong kecil-kecil.

\section{Ekstraksi Sampel}

Daun Beluntas yang telah dikeringkan sebanyak 550 g diekstraksi secara maserasi dengan menggunakan 5 liter etanol 70\% selama 3 x 24 jam sambil sesekali diaduk pada temperatur kamar, kemudian dilakukan penyaringan. Ampasnya kembali dimaserasi dengan metode dan pelarut yang sama hingga pelarutnya hampir jernih. Filtrat yang diperoleh kemudian digabung, selanjutnya pelarutnya diuapkan dengan menggunakan rotary evaporator hingga diperoleh ekstrak kental (Bahar MA et al, 2015; Mufidah Met al, 2015).

\section{Pembuatan Larutan koloidal Natrium CMC $\mathbf{0 , 1 \%} \mathrm{b} / \mathrm{v}$}

Sebanyak 0,25 g Natrium CMC (Na CMC) dimasukkan ke dalam labu Erlenmeyer $250 \mathrm{ml}$, lalu ditambahkan air suling panas dengan suhu $70^{\circ} \mathrm{C}$ sedikit demi sedikit dan diaduk menggunakan pengaduk elektrik hingga 
homogen hingga terbentuk suspensi yang jernih, kemudian dicukupkan dengan air panas hingga volume $250 \mathrm{ml}$.

\section{Pembuatan Suspensi Natrium Diklofenak}

Ditimbang 20 tablet dan dihitung bobot rataratanya kemudian digerus dan diambil bobot setara 2,25 mg/Kg BB kemudian disuspensikan dengan $\mathrm{Na} \mathrm{CMC}$.

\section{Pembuatan Suspensi Ekstrak Beluntas}

Ekstrak daun Beluntas disuspensikan di dalam Na CMC 0,1\% dengan konsentrasi 1, 3, dan 5 $\%$ untuk pemberian pada hewan dengan dosis yang setara dengan $100 \mathrm{mg} / \mathrm{Kg} \mathrm{BB}, 300 \mathrm{mg} / \mathrm{Kg}$ $\mathrm{BB}, 500 \mathrm{mg} / \mathrm{Kg} \mathrm{BB}$.

\section{Pemilihan dan Perlakuan Hewan Uji}

Hewan yang digunakan adalah mencit (Mus musculus) yang berbadan sehat, berumur sekitar 2-3 bulan, yang dapat diamati dari perilakunya dengan bobot badan 20-30 g. Mencit sebanyak 15 ekor dibagi kedalam 5 kelompok perlakuan, tiap kelompok terdiri dari 3 ekor mencit. Kelompok I sebagai kontrol negatif, kelompok II, III, dan IV sebagai kelompok perlakuan, dan kelompok V sebagai kontrol positif. Kontrol negatif diberikan $\mathrm{Na}$ CMC, kelompok perlakuan diberikan ekstrak Beluntas dengan konsentrasi berbeda dan kontrol positif diberikan dengan natrium diklofenak secara peroral dengan dosis 2,25mg/Kg BB. Pengukuran volume udema dilakukan setelah 1 jam perlakuan.
Pembuatan Model Inflamasi Terinduksi CFA (Complete Freund's Adjuvant)

Mencit disuntikan CFA sebanyak $40 \mu \mathrm{l}$ pada bagian ipsilateral dan aqua pro injection sebanyak $40 \mu \mathrm{l}$ pada bagian kontralateral secara intraplantar dan dilakukan pengamatan setiap hari selama 18 hari.

\section{Penentuan Volume Udema}

Dilakukan pengamatan laju penurunan volume edema kaki mencit menggunakan alat pletismometer dengan pengulangan sebanyak 3 kali kemudian dihitung rata-ratanya.

\section{Pengumpulan dan Analisis Data}

Data yang diperoleh berupa volume udema dari beberapa perlakuan dianalisis secara statistik dengan menggunakan metode Two Way RM ANOVA diikuti Bonferronni post test dengan bantuan software Graphpad prisim 5,03 (Graphpad Software, La Jolla, California).

\section{HASIL DAN PEMBAHASAN}

Pada penelitian ini diawali dengan melakukan ekstraksi daun Beluntas $(P$. indica L.) Daun Beluntas yang telah dikeringkan diekstraksi menggunakan metode maserasi dengan pelarut etanol $70 \%$ selama 3 x 24 jam. Ektraksi dengan metode maserasi dipilih karena untuk menghindari kemungkinan rusaknya senyawa kimia yang diakibatkan adanya pemanasan. Hasil dari proses ekstraksi $550 \mathrm{~g}$ daun Beluntas diperoleh 93,51 g ekstrak etanol (Rendamen 17,01\%). Ekstrak yang telah diperoleh selanjutnya suspensikan menjadi beberapa konsentrasi kemudian diberikan kepada mencit sebagai obat. 
Penggunaan CFA sebagai penginduksi dikarenakan senyawa ini akan menstimulasi fagositosis, sekresi sitokin oleh fagositosis mononuklear, sehingga berbagai jenis sitokin seperti TNF $\alpha$, IL-1, IL-6, IL-8, PGE-2, NO, MMP dan mediator lainnya akan dilepaskan (Fajrin FAdkk., 2013).

Penelitian ini menggunakan parameter kecepatan penyembuhan udema sesaat (akut) dan 18 hari (subkronis) setelah diberikan penginduksi. Nilai selisih hari penyembuhan volume udema menunjukkan besarnya efektivitas bahan uji. Semakin cepat penurunan volume udema yang didapatkan maka semakin besar efek antiinflamasi yang terdapat dalam bahan uji dan apabila selisih penurunan volume udema semakin lambat maka bahan uji tersebut memiliki efek antiinflamasi yang minimal dalam menghambat volume udema. Salah satu parameter terjadinya inflamasi adalah terbentuknya udema. Jika penggunaan suatu obat tradisional atau sintetik dapat menurunkan udema yang diinduksi dengan CFA, maka obat tersebut dapat dikatakan mempunyai efek sebagai antiiflamasi. Besarnya efektivitas antiinflamasi bergantung pada besarnya efek kecepatan penyembuhan yang didasari dari besarnya penurunan volume udema yang terlihat.

Penelitian ini menggunakan parameter kecepatan penyembuhan udema sesaat (akut) dan 18 hari (subkronis) setelah diberikan penginduksi. Nilai selisih hari penyembuhan volume udema menunjukkan besarnya efektivitas bahan uji. Semakin cepat penurunan volume udema yang didapatkan maka semakin besar efek antiinflamasi yang terdapat dalam bahan uji dan apabila selisih penurunan volume udema semakin lambat maka bahan uiji tersebut memiliki efek antiinflamasi yang minimal dalam menghambat volume udema.

Pada gambar 1 terlihat bahwa terjadi peningkatan volume udema pada bagian ipsilateral CFA sedangkan pada bagian kontralateral yang diinduksi dengan API tidak terdapat peningkatan volume udema yang sifatnya persisten karena hanya dalam waktu 24 jam telah terjadi penurunan volume udema. Selain itu, baik kontrol positif maupun perlakuan belum memberikan efek penurunan volume udema ataupun memberikan penghambatan pembentukan udema secara akut. Sedangkan pada gambar 2 terlihat bahwa perlakuan yang diberikan selama 18 hari berhasil menurunkan volume udema pada kaki mencit dan pada tabel 1 terlihat bahwa hari penyembuhan tercepat terlihat pada kelompok kontrol positif kemudian diikuti ekstrak daun Beluntas dengan konsentrasi $300 \mathrm{mg} / \mathrm{Kg} \mathrm{BB}$, setelah itu konsentrasi $500 \mathrm{mg} / \mathrm{Kg}$ BB dan yang paling rendah adalah konsentrasi $100 \mathrm{mg} / \mathrm{Kg}$ BB. Sedangkan, kelompok kontrol negatif belum mengalami penyembuhan walaupun terjadi penurunan volume udema. Hasil analisis secara statistik menunjukkan bahwa terdapat perbedaan yang sangat signifikan $(* * * \mathrm{P}<0,001)$ antara kelompok perlakuan dan kontrol positif terhadap kontrol negatif dalam menurunkan volume udema mencit yang telah diinduksi inflamasi. 


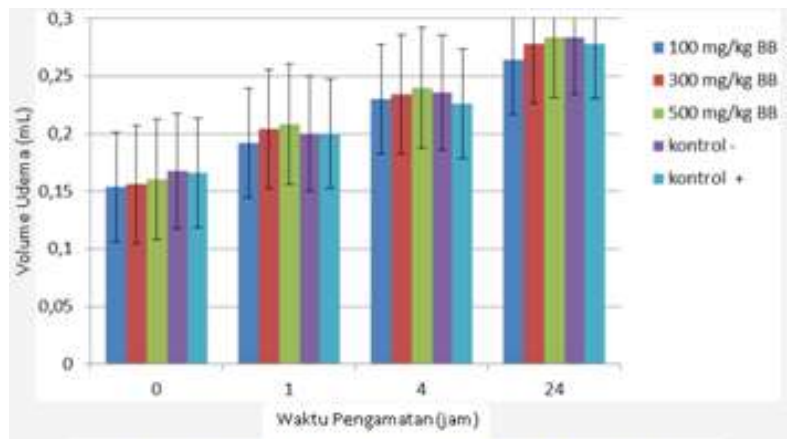

Keterangan:Dilakuan pengamatan tiap jam setelah dinduksi oleh CFA dan diberikan perlakuan oral menggunakan ekstrak dengan 3 konsentrasi, kontrol - $(\mathrm{Nz}$ (MC), dan kontrol + (Na.Diklofenak).

(a)

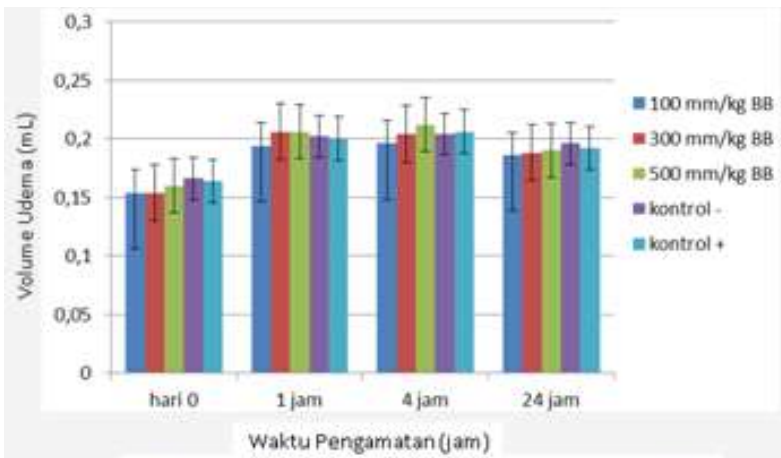

Keterangan:Dilakuan pengamatan tiap jam setelah dinduksi oleh CFA dan diberikan perlakuan oral menggunakan ekstrak dengan 3 konsentrasi, kontrol - ( $\mathrm{NaCMC})$, dan kontrol + (Na.Diklofenak).

(b)

Gambar 1. (a) Grafik volume udema fase akut kaki kanan (ipsilateral), (b) Grafik volume udema fase akut kaki kiri (kontralateral)

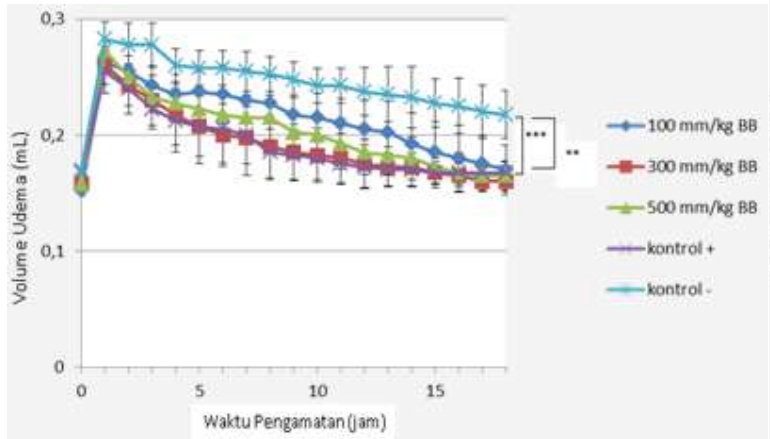

Keterangan: Diberikan perlakuan per oral tiap hari setelah diinduksi oleh CFA menggunakan ekstrak dengan 3 konsentrasi, kontrol - $(\mathrm{Na}$ CMC), dan kontrol + (Na.Diklofenak). ${ }^{* * 8}=\mathrm{p}<0,001,{ }^{* 8}=\mathrm{p}<0,01$

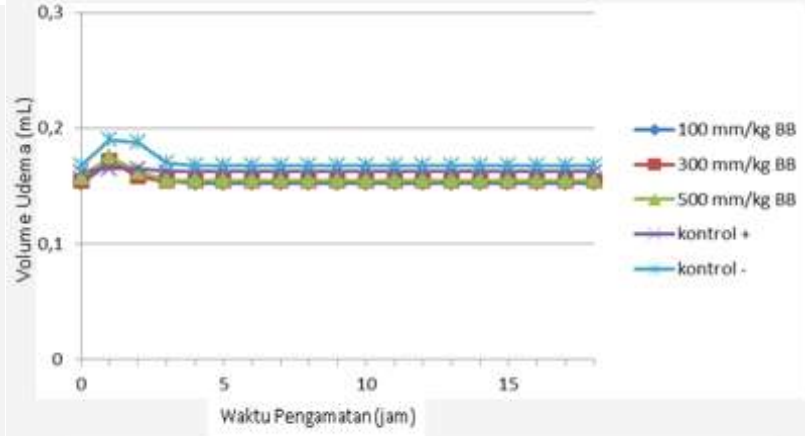

Keterangan: Diberikan perlakuan per oral tiap hari setelah diinduksi oleh CFA menggunakan ekstrak dengan 3 konsentrasit, kontrol - $(\mathrm{Na}$ CMC), dan kontrol + (Na.Diklofenak). ${ }^{* * 8}=p=0,001,{ }^{* *}=p=0,01$

Gambar 2. (a) Grafik volume udema fase subkronis kaki kanan, (b) Grafik volume udema fase subkronis kaki kiri

Tabel 1.Kecepatan hari penyembuhan udema pada kaki kanan mencit.

\begin{tabular}{crrrr}
\hline \multicolumn{1}{c}{ Dosis } & \multicolumn{3}{c}{ Replikasi (hari ke-) } & \multirow{2}{*}{ Rata-rata } \\
\cline { 2 - 4 } & 1 & 2 & 3 & \\
$100 \mathrm{mg} / \mathrm{Kg} \mathrm{BB}$ & 15 & 18 & 20 & 17,67 \\
$300 \mathrm{mg} / \mathrm{Kg} \mathrm{BB}$ & 17 & 12 & 7 & 12,00 \\
$500 \mathrm{mg} / \mathrm{Kg} \mathrm{BB}$ & 16 & 11 & 16 & 14,33 \\
Kontrol + & 8 & 8 & 12 & 9,33 \\
\hline
\end{tabular}

Berdasarkan hasil tersebut maka dilakukan uji lanjutan menggunakan benferroni test untuk melihat level signifikansi antar perlakuan terhadap kontrol positif dan kontrol negatif, juga untuk melihat perbedaan intra perlakuan ditiap-tiap hari perlakuan. Diperoleh hasil bahwa untuk ekstrak daun Beluntas 100 $\mathrm{mg} / \mathrm{Kg}$ BB terhadap kontrol negatif, tidak terdapat perbedaan yang signifikan dalam menurunkan volume udema kecuali setelah 14 hari perlakuan. Hal ini menunjukkan untuk dosis rendah ekstrak daun Beluntas 
memerlukan waktu yang lebih lama untuk dapat berefek. Lain halnya dengan dengan ektrak daun Beluntas $300 \mathrm{mg} / \mathrm{Kg}$ BB terhadap kontrol negatif, setelah hari ke 3 pebedaan yang signifikan sudah mulai terlihat dengan level yang sangat signifikan $(* * * \mathrm{p}<0,001)$ di hari ke 6 hingga hari 18. Namun ditemukan hal yang menarik dalam pengamatan yaitu pengaruh ekstrak Beluntas $500 \mathrm{mg} / \mathrm{Kg}$ BB dibandingkan dengan kontrol negatif dalam menurunkan volume udema. Perbedaan signifikan (** $\mathrm{p}<0,01)$ baru ditemukan setelah hari ke 8 perlakuan. Berdasarkan hasil ini kami menarik kesimpulan bahwa dosis maksimal yang berefek adalah $300 \mathrm{mg} / \mathrm{Kg}$ BB. Dosis yang melebihi itu dapat menyebabkan efektivitas ekstrak daun Beluntas menjadi menurun. Meskipun demikian diperlukan uji lebih lanjut untuk menganalisis mekanisme ekstak daun Beluntas dan pengaruh konsentrasi komponen ekstak tersebut dalam menurunkan volume udema. Kemungkinan hal ini dipengaruhi oleh kandungan ekstrak daun Beluntas, dimana semakin tinggi konsentrasi eksrak maka semakin tinggi konsentrasi salah satu komponen yang kemungkinan mempengaruhi mekanisme penurun volume udema.

Analisis statistika antara kelompok perlakuan terhadap kelompok kontrol positif ditemukan tidak terdapat perbedaan signifikan dalam menurunkan volume udema baik dosis $100 \mathrm{mg} / \mathrm{Kg} \mathrm{BB}, 300 \mathrm{mg} / \mathrm{Kg}$ BB hingga 500 mg/Kg BB. Hal ini menunjukkan bahwa ekstrak daun Beluntas memiliki antiinflamasi yang baik.
Berdasarkan gambar $2 \mathrm{~b}$, terlihat bahwa pemberian ekstrak etanol daun Beluntas sendiri tidak menyebabkan adanya peningkatan volume udema karena tidak adanya perubahan volume udema setelah sembuh pada hari ke 3 .

Daun Beluntas mengandung alkaloid, flavonoida, tanin, minyak atsiri, asam chlorogenik, natrium, kalium, aluminium, kalsium, magnesium, dan fosfor. Flavonoid, minyak atsiri, dan tanin dilaporkan memiliki aktivitas anti inflamasi. Flavonoid akan menghambat kerja dari COX-2 sehingga produksi dari prostaglandin menurun (Gautama VG, 2015). Tanin akan menyumbangkan atom hidrogen untuk mengikat dan menetralkan radikal bebas sehingga mengendalikan dan mengurangi reaksi autooksidasi lipid dengan cara melindungi membran sel tubuh dalam mengurangi inflamasi (Putri, BPdkk, 2013). Kandungan minyak atsiri daun Beluntas yang diduga memiliki efek antiinflamasi adalah eugenol (Susanti A., 2007). Eugenol dilaporkan dapat menghambat agregasi platelet dengan cara menghambat pembentukan tromboksan sehingga juga berperan dalam efek antiinflamasi. Eugenol juga dapat menghambat aktivitas PGH sintase karena berkompetisi dengan asam arakhidonat pada sisi aktif PGH sintase sehingga menghambat pembentukan PG (Hidayati NA dkk., 2008). Sehingga, Efek antiinflamasi dari Beluntas kemungkinan bekerja pada satu atau campuran mekanisme diatas. 


\section{KESIMPULAN}

Berdasarkan hasil penelitian diperoleh kesimpulan bahwa ekstrak etanol daun beluntas dengan memberikan efek antiinflamasi yang baik.

\section{DAFTAR PUSTAKA}

Bahar, M. A., Alam, G., Manggau, M. A., Mufidah, M., \& Suparman, S. (2015). Bioassay-guided Fractination Of Antimitotic Compound from Ongkea Cortex (Mezzettia Parviflora Becc) towards Sea Urchin Eggs. Journal of Tropical Pharmacy and Chemistry, 3(1).

Craig C.R. and Stitzel R.E. (2003). Modern Pharmacology with Clinical Aplications (5 ${ }^{\text {th }}$ ed.). Philadelphia: Walters Kluwer Health;. Hal.424

Dalimartha S. (1999). Atlas Tumbuhan Obat Indonesia Jilid 1. Jakarta: Trubus Agriwidya.. Hal.18-21

Fajrin F.A, Khotib J, \& Susilo I. Histologi Dorsal Horn Dari Spinal Cord Mencit yang Mengalami Nyeri Inflamasi Akibat Induksi CFA (Completed Freund's Adjuvant) Setelah Pemberian Gabapentin dan Baclofen. (2013). Bul. Peneliti Kesehatan. Vol. 41, No. 4. Hal. $225-236$

Harvey R.A, Clark M.A, Finkel R, et.al. (2012). Lippincott's Illustrated Reviews:Pharmacology(5th ed). Philadelphia: Walters Kluwer Health. Hal. 525

Hidayati, N.A., Ahmad, S.L., \&Setyawan, D. Kandungan Kimia dan Uji Antiinflamasi Ekstrak Etanol Lantana camara L. pada Tikus Putih (Rattus norvegicus L.) Jantan. (2008). Bioteknologi.Surakarta: 10-17, Mei, ISSN: 0216-6887. Hal. 16
Murdifin, Mufidah, et al. (2015). Antiatherogenic effect of Mezzetia parviflora BECC. extract in high cholesterol fed rats. Journal of Chemical and Pharmaceutical Research. 7.5: 499-505.

National Institutes of Health Intramural.Guidelines for the Research Use of Adjuvants. ARAC [serial on the internet]. (2011, November). Available from:

oacu.od.nih.gov/ARAC/documents/Adj uvants.pdf

Putri, B.P., Aulanni'am, \& Padaga, M.C. (2013). Terapi Ekstrak Air Buah Kesemek (Diospyros kaki L,f,) pada Tikus (Rattus novergicus) Artritis terhadap Enzim Superoksida Dismutase (SOD) dan Gambaran Histologi Jaringan Sendi. Student Journal Vol. 2, No. 2.

Ricciotti E \& FitzGerald G.A. (2011). Prostaglandins and Inflammation. Arterioscler Thromb Vasc Biol.31: 9861000.

Sibarani V.R, Wowor P.M, \&Salem H.A. (2013). Uji Efek Analgesik Ekstrak Daun Beluntas (Pluchea Indica (L.) Less.) pada Mencit (Mus musculus). Jurnal e-Biomedik (eBM), Volume 1, Nomor 1, Hal. 621-628

Srisook K, Buapool D, Boonbai R, Simmasut P, Charoensuk Y, \& Srisook E. (2012). Antioxidant and Anti-Inflammatory Activities of Hot Water Extract from Pluchea indica Less. Journal of Medicinal Plants Research. Vol. 6(23): 4077-4081.

Susanti, A. (2007). Daya antibakteri ekstrak etanol daun beluntas (Pluchea indica less) terhadap Escherichia coli secara in vitro. Skripsi thesis, Universitas Airlangga. Surabaya. 